\title{
Leiden Ameliyathane ve Yoğun Bakım Güvenliği Ölçeği’nin Türkçe’ye Uyarlanması
}

\author{
Adaptation toTurkish of the Leiden Operating Theatre and Intensive Care Safety Scale
}

\author{
Yasemin ALTINBAŞ ${ }^{1}$, Özlem SOYER ER ${ }^{2}$, Meryem YAVUZ van GIERSBERGEN ${ }^{3}$
}

\begin{abstract}
${ }^{1}$ Adıyaman Üniversitesi, Sağlık Bilimleri Fakültesi, Hemşirelik Bölümü, Adıyaman, Türkiye
${ }^{2}$ Afyonkarahisar Sağlık Bilimleri Üniversitesi, Sağlık Bilimleri Fakültesi, Hemşirelik Bölümü, Afyon, Türkiye

${ }^{3}$ Ege Üniversitesi, Hemşirelik Fakültesi, Cerrahi Hastalıkları Hemşireliği Anabilim Dalı, İzmir, Türkiye
\end{abstract}

\section{Özet}

Amaç: Bu çalışmanın amacı Leiden Ameliyathane ve Yoğun Bakım Güvenliği Ölçeği’nin Türkçe’ye uyarlanmasıdır.

Gereç ve Yöntemler: Bu çalıșma, metodolojik bir araştırmadır. Araştırma verileri, iki üniversite hastanesinde ameliyathane ve yoğun bakım ünitelerinde en az 1 yıldır çalışan, 18 yaşından büyük 319 sağlık çalışanıyla Nisan-Haziran 2019 tarihleri arasında toplandı. Verilerin toplanmasında, "Sağlık Çalışanlarının Sosyodemografik ve Mesleki Özellikler Formu” ve "Leiden Ameliyathane ve Yoğun Bakım Güvenliği Ölçeği” kullanıldı. Sağlık çalışanlarının sosyodemografik ve klinik özellikleri tanımlayıcı testlerden sayı, yüzde, ortalama ve standart sapma ile analiz edildi. Geçerlik ve güvenirlik yapılırken iç tutarlılık, dil, kapsam ve yapı geçerliği incelendi.

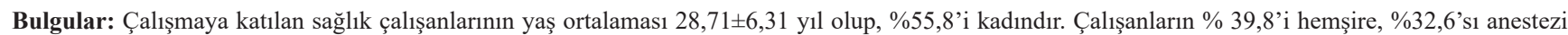
uzmanı, \%18,8'i hekim, \%4,7'si anestezi teknisyeni ve \%4,1'i de ameliyathane teknikeridir. Dil geçerliği sağlanan ölçeğin kapsam geçerlik indeksi 0,99 bulundu. Ölçeğin Cronbach $\alpha$ katsayısı 0,89 olup yüksek güvenirlik derecesine sahip olduğu belirlendi. Madde toplam puan korelasyonunda 12., 13., 16., 17., 19., 46., 52., 54., 55. ve 59. maddeler hariç diğer tüm maddelerin korelasyon katsayıları 0,258 ile 0,666 arasında ve p<0,001 olarak bulundu. 40 madde ile yapılan açıklayıcı faktör analizinde, faktörler: Ekip Çalışması ve Farkındalık, Kaynak Yönetimi ve Planlama, Çalışan Kaynakları ve Denetim, Ekip Çalışma Talimatları ve Hazırlıklar ve Eğitim ve Bilgiye Ulaşma olarak belirlendi.

Sonuç: Leiden Ameliyathane ve Yoğun Bakım Güvenliği Ölçeği’nin Türk toplumunda ameliyathane ve yoğun bakımlarda, hasta güvenliğinde olabilecek gizli sistem risk faktörlerinin belirlenmesinde geçerli ve güvenilir bir araç olduğu saptandı. Ölçeğin farklı hastanelerin ameliyathane ve yoğun bakım ünitesinde çalışan sağlık çalışanlarına uygulanması önerilmektedir.

Anahtar kelimeler: Ameliyathane, Hasta Güvenliği, Sağlık Çalışanı, Yoğun Bakım.

\begin{abstract}
Objective: The aim of this study was to adapt for Turkish of The Leiden Operating Theatre and Intensive Care Safety Scale.

Material and Methods: This study is a methodological research. Data were collected between April-June 2019 with 319 healthcare workers older than 18 years working in the operating theatre and intensive care units of two university hospitals for at least 1 year. "Sociodemographic and Occupational Characteristics of Health Workers Form" and "Leiden Operating Theatre and Intensive Care Safety Scale" were used to collect the data. Sociodemographic and clinical characteristics of healthcare workers were analyzed by number, percentage, mean and standard deviation from descriptivetests. Internal consistency, language, content and construct validity were examined while making validity and reliability.

Results: The mean age of health workers participating in the study was $28.71 \pm 6.31$ years and $55.8 \%$ were women. $39.8 \%$ of the employees are nurses, $32.6 \%$ are anesthesiologists, $18.8 \%$ are physicians, $4.7 \%$ are anesthesia technicians and $4.1 \%$ are operating technicians. The validity of the scale was 0.99 . In the explanatory factor analysis conducted with 40 items, factors were determinent as Team work and Awareness, Resource Management and Planning, Employee Resources and Audit, Team Work Instructions and Preparations and Training and Access to Information.

Conclusion: The Leiden Operating Theatre and Intensive Care Safety Scale was found to a valid and reliable tool for Turkish community in determining the hidden system risk factors that may be in patient safety in operating theatres and intensive care units.

Keywords: Operating theatre, Patient safety, Health worker, Intensive care.
\end{abstract}

Yazışma adresi: Yasemin ALTINBAŞ, Adıyaman Üniversitesi, Sağlık Bilimleri Fakültesi, Hemşirelik Bölümü, Adıyaman,Türkiye Telefon: +90 416 2233800-4620, Mail: yaseminaltinbas_27@hotmail.com

ORCID No (Sirasıyla): 0000-0002-0456-3236, 0000-0002-9272-2400, 0000-0002-8661-0066

Geliş tarihi: 10.09 .2020

Kabul tarihi: 02.10 .2020

DOI: $10.17517 / \mathrm{ksutfd} .793167$ 


\section{GÍRIŞ}

Sağlık hizmetlerinin gelişimi ve hastaların haklarını öğrenmesiyle birlikte sağlık bakım hizmeti sunumunda çeşitlilik ve kalite giderek ön plana çıkmaktadır. Sağlık bakım hizmeti sunumunda çeşitlilik ve kaliteyi öne çıkaran konulardan en önemlisi hasta güvenliğidir (1). Hasta güvenliği, eski çağlardan beri var olan bir konudur. MÖ. 1700’lerdeki Hammurabi kanunlarında, "Hekimin hastasını öldürmesi veya tehlikeli bir şekilde yaralaması halinde, her iki elinin kesileceği..." (Madde 219) yazılmıştır. Daha sonraları, "Primum non nocere" (önce zarar verme) ilkesi benimsenmiştir $(2,3)$. Birçok hasta, hastanede bulunduğu süre içinde tedavi edilirken ya da bakım verilirken önlenebilir bazı hatalar nedeni ile zarar görebilmektedir (3). Hasta güvenliğinin en basit tanımı, sağlıkla ilişkili hastalarda yapılan hataların ve yan etkilerin önlenmesidir (4). Sağlık sektörünün karmaşık yapısı, aşırı iş yükü, hastalara yeterli süre ayıramama, eğitim yetersizliği, sağlık politikalarının ve prosedürlerinin doğru bir şekilde uygulanmaması gibi nedenlere bağlı olarak ilaç hataları, önlenebilir enfeksiyonlar, cerrahi ve tanı ile ilgili ve tıbbi ekipmandan kaynaklanan hatalar (2), çalışanlar arasındaki yetersiz iletişim ve işbirliği ve insan gücü eksikliği $(5,6)$ maksimum performans sınırlarının zorlanması, profesyonel otonomi, takım oyuncusu yaklaşımına geçişte zorlanma, hasta güvenliğine sistematik yaklaşım eksikliği ve profesyonel kural ve yasalardaki karmaşıklık (7) sağlık sisteminde sıklıkla karşılaşılan ve hasta güvenliğini tehdit eden hatalardan bazılarıdır.

Sağlık çalışanlarının güvenli, kaliteli ve verimli sağlık hizmeti sunması; çalışanların kapasitesine ve performansta mükemmelliği destekleyen bir ortama sahip olmasına bağl1dır. Sağlık çalışanları bir yandan işlerinin gereğini yaparken iş kazaları yaşayabilmekte ya da meslek hastalıkları geçirebilmekte, aynı zamanda uygunsuz çalışma koşullarında ciddi hasta güvenliği ihlallerine sebep olabilmekte ya da tıbbi hatalar ortaya çıkabilmektedir (8). Bu nedenle, literatürde sağlık çalışanlarının hasta güvenliği uygulamalarındaki etkinliğini gösteren birçok çalışma mevcuttur (1,5,8,10,12-14,18). Meslek grupları arasında hemşireliğin doğası her ortamda hastayı tehlikelerden korumak ve güvenli bakım vermek olduğu için bu alanda hemşireler, önemli sorumluluklar alarak mesleği daha görünür kılmada etkin çaba harcamaktadırlar (3). Örneğin hemşirelik bakımı açısında baktığımızda, günlük hasta başına ek bir hemşire ilavesi ile 30 günlük ölüm oranında \%50, hemşire bakım saatinde 0.25 lik ilave ile ölüm oranında \%20 azalma sağlandığı saptanmıştır (9). Günlük hasta başına verilen hemşirelik bakım saatinde bir saatlik artışın sağlanmasıyla pnömoni vakalarında $\% 8,5$; günlük hasta başına verilen hemşirelik bakım saatinde \%10'luk bir artışla ise \% 9,5 oranında azalma olduğu belirlenmiştir. Hemşirelik bakım saatinde artış ile bası yaralarında da azalma gözlendiği belirlenmiştir (10). Cerrahi müdahale sonrası hasta başına verilen günlük tam hemşirelik bakım saati ile idrar yolu enfeksiyonları, pnömoni, tromboz ve akciğer rahatsızlıkları riski arasında ilişki olduğu saptanmıștır. Araștırma sonuçları efektif bir hasta bakımı ile hasta güvenliğini tehdit edebilecek birçok komplikasyonun önlenebileceğini açıkça göstermektedir $(6,11)$.

Ameliyathaneler ve cerrahi yoğun bakım üniteleri; hastaların savunmasız olduğu, son derece gelişmiş donanıma sahip, çalışanların özel bilgi, beceri ve donanıma sahip olması gereken, iş süreçleri karmaşık, ekip çalışmasının gerekli olduğu, yoğun çalışma ortamına sahip, sürekli dikkat gerektiren, tıbbi hatalar açısından riskli, stresli, yoğun baskı hissedilen ve disiplinler arası uygulamalar gerektiren son derece özellikli birimlerdir $(5,12-15)$. Cerrahi bakımda hasta güvenliğini sağlamak üzere Dünya sağlık Örgütü 'Güvenli Cerrahi Hayat Kurtarır’ kampanyasını 2008 yılında başlatmış ve cerrahide hasta güvenliğinin oldukça önemli olduğunu vurgulamıştır (16). Hastanelerde gerçekleşen tıbbi hataların \%50'sinin cerrahi bölümlerde yaşandığı ve bunların da \% 50'sinin güvenli cerrahi uygulamaları ile önlenebildiği vurgulanmaktadır $(15,17)$. Günümüzde hasta güvenliğinin sağlanması sağlık kurumlarının önündeki en önemli konudur. Hasta bakım sunumundaki değişkenlikler ciddi bir risk teşkil etmektedir ve bu risklerin ortaya çıkardığı sorunlar sadece bunların sigortalanması ile çözülememektedir. Yapılması gereken risklerin yönetilmesi yoluyla azaltılmasına odaklanmak olmalıdır (18). Bu bağlamda Leiden Ameliyathane ve Yoğun Bakım Güvenliği Ölçeği, ameliyathane ve yoğun bakım ünitesinde hasta güvenliğinde istenmeyen olaylara yol açan sisteme dayalı gizli risk faktörlerini değerlendiren kapsamlı bir ölçüm aracı olarak geliştirilmiştir (19). Bu çalışmanın amacı, Leiden Ameliyathane ve Yoğun Bakım Güvenliği Ölçeği'nin Türkçe'ye uygunluğunu değerlendirmek ve geçerli ve güvenilir bir ölçüm aracı olup olmadığını incelemektir.

\section{GEREÇ ve YÖNTEMLER}

Bu çalışma, Leiden Ameliyathane ve Yoğun Bakım Güvenliği Ölçeği'nin Türkçe’ye uyarlanması amacıyla yapılmış metodolojik bir çalışmadır. Araştırma, iki üniversite hastanesinde Nisan-Haziran 2019 tarihleri arasında yapıldı. Araştırmanın evrenini iki üniversite hastanesinde Nisan-Haziran 2019 tarihleri arasında ameliyathane ve yoğun bakım ünitelerinde en az 1 yıl süreyle çalışan, 18 yaşından büyük sağlık çalışanları oluşturdu. Metodolojik araştırmalarda örneklem sayısının ölçek madde sayısının en az beş katı olması önerilmektedir (20). Leiden Ameliyathane ve Yoğun Bakım Güvenliği Ölçeği 59 madde içerdiğinden, araştırmanın örneklemine ölçek madde sayısının en az 5 katı olacak şekilde en az 295 sağlık çalışanı dahil edilmesi planlandı. Ölçeğin faktör yapısını ortaya çıkarabilecek genişlikte bir örnek büyüklügü alınmaması sonuçları olumsuz etkileyecektir. Literatürde örneklemin 200'den az olmasının psikometrik yapıyı ortaya çıkarmak için yeterli olmayabileceği, bir testin faktör yapısını ortaya çıkarmak için 300 ün, ideal olarak 500'ün üzerinde örnek alınması gerektiği vurgulanmaktadır (21). Araştırmanın örneklemine her iki üniversite hastanesinin ameliyathane ve yoğun bakımlarında çalışan ve çalışmaya katılmayı gönüllü olarak kabul eden 319 hekim, hemşire, anestezi uzmanı, anestezi teknikeri ve ameliyathane teknikeri dahil edildi. 


\section{Veri Toplama Araçları}

Verilerin toplanmasında; "Sağlık Çalışanlarının Sosyodemografik ve Mesleki Özellikler Formu" ve "Leiden Ameliyathane ve Yoğun Bakım Güvenliği Ölçeğì” kullanıldı.

\section{Sağlık Çalışanlarının Sosyodemografik ve Mesle- ki Özellikler Formu}

Bu formda, sağlık çalışanlarının sosyodemografik özellikleri ve çalışma ortamını etkileyebileceği düşünülen mesleki özellikleri yer almaktadır. Bu özellikler arasında sağlık çalışanlarının yaşı, cinsiyeti, öğrenim durumu, mesleği, meslekte çalışma yilı, çalıştığı hastane, çalıştığı birim ve bu birimdeki çalışma yılı bilgilerini içeren araştırmacılar tarafindan oluşturulan 8 soru yer almaktadır.

\section{Leiden Ameliyathane ve Yoğun Bakım Güvenliği} Ölçeği

Leiden Ameliyathane ve Yoğun Bakım Güvenliği Ölçeği, ameliyathane ve yoğun bakım ünitesinde istenmeyen olaylara yol açan sisteme bağlı gizli risk faktörlerini, birimlerdeki ve tıbbi disiplinlerdeki sistem faktörlerine dair çalışanların cevaplarını karşılaştırarak değerlendiren kapsamlı bir ölçüm aracı olarak geliştirilmiştir $(19,22)$. Van Beuzekom ve ark., tarafından (2007) Leiden Ameliyathane ve Yoğun Bakım Güvenliği Ölçeğinin geliştirildiği araştırmada ölçek 11 alt boyuttan oluşmaktadır (19). Bu alt boyutlar, eğitim (6 madde, Cronbach a:0.81), iletişim/bilgiye ulaşma (6 madde, Cronbach a:0.84), planlama ve koordinasyon (3 madde, Cronbach a:0.75), tasarım (4 madde, Cronbach $\alpha: 0.76$ ), donanım bakı$\mathrm{m} 1$ (4 madde, Cronbach $\alpha: 0.87$ ), malzeme kaynakları (5 madde, Cronbach a:0.75), ekip talimatları (3 madde, Cronbach a:0.76), ekip çalıșması (4 madde, Cronbach $\alpha: 0.75$ ), durum farkındalığı (4 madde, Cronbach a:0.79), çalıșan kaynakları (6 madde, Cronbach $\alpha: 0.75$ ), ve prosedürler (6 madde, Cronbach a:0.81)'dir (19). Daha sonra ölçeğin düzenlenmesi esnasında katılımcıların önerisi üzerine ölçeğe 2 alt boyutun daha ilave edilmesine yazarlar tarafından karar verilmiştir. Bu alt boyutlar düzenlilik (3 madde), hiyerarşi (5 madde)'dir. Ölçek toplamda 13 alt boyut ve 59 maddeden oluşmaktadır, ölçekten alınabilecek en düşük puan 59, en yüksek puan 236 dır (19).Ölçeğe verilen cevaplar 4 puanlık ( $1=$ tamamen katılmıyorum, $2=$ katılmiyorum, 3=katıliyorum, 4=tamamen katıllyorum) likert tipte değerlendirilmektedir. Tüm alt boyutların Cronbach $a$ değerleri 0.75 ile 0.88 arasındadır. Leiden Ameliyathane ve Yoğun Bakım Güvenliği Ölçeği alt boyutları ile güvenlik kültürü arasındaki korelasyon orta dereceli ve beklenen yönde olmuştur. Yüksek puanlar çalışma koşulları hakkında daha olumlu algılamaları göstermektedir (19).

\section{Verilerin Toplanması ve İstatistiksel Analiz}

Sağlık çalışanlarına veri toplama araçları uygulanmadan önce çalışma konusunda bilgi verilmiş, araştırmaya katılmak için gönüllü olanlara veri toplama formları uygulanmıştır. Veri toplama formları 3 aylık veri toplama sürecinde 08-16 saat/gün, 16-08 saat/gün şiftleri şeklinde çalışan sağlık çalışanlarına ameliyathane ve yoğun bakım ünitelerinde uygu- lanmıştır ve uygulanan formların doldurulması yaklaşık 20 $\mathrm{dk}$ sürmüștür.

Araştırmadan elde edilen verilerin analizi SPSS paket programı (IBM SPSS Statistics for Windows, Version 21.0. Armonk, NY: IBM Corp.) kullanılarak analiz yapıldı. Sağlık çalışanlarının sosyodemografik ve mesleki özellikleri, sayı, yüzde, ortalama ve standart sapma içeren tanımlayıcı testler ile analiz edildi.

Leiden Ameliyathane ve Yoğun Bakım Güvenliği Ölçeğinin Türkçe’ye uyarlanması ve geçerliğinin incelenmesinde dil geçerliği İngilizce’den Türkçe’ye, Türkçe’den İngilizce’ye geri çeviri şeklinde yapıldı ve 10 uzman görüşü alındı.

Kapsam geçerliği için Kapsam Geçerlik İndeksi (KGİ) hesaplandı. Kapsam geçerliğinin sayısal değerlerle kanıtlanması için, araştırmacı tarafından geliştirilen bir dereceleme ölçütü uzmanlara verildi. Kapsam geçerliliği Davis (1992) tarafından geliştirilen teknikle yapıldı. Davis tekniği uzman görüşlerini; "a)uygun, b)madde hafifçe gözden geçirilmeli, c)madde ciddi olarak gözden geçirilmeli ve d)madde uygun değil" şeklinde dörtlü derecelendirmektedir (23). Bu teknikle (a) ve (b) seçeneğini işaretleyen uzmanların sayısının toplam uzman sayısına bölünüp bir çıkarılarak maddeye ilişkin KGİ elde edilmektedir ve bu değer istatistiksel bir ölçütle karşılaştırmak yerine 0.80 değeri ölçüt olarak kabul edilmektedir $(23,24)$. Uzman görüşleri değerlendirildikten sonra Leiden Ameliyathane ve Yoğun Bakım Güvenliği Ölçeği ameliyathane ve yoğun bakımlarda çalışan sağlık çalışanlarına uygulandı.

Güvenilirlik iç tutarlılık testleri Cronbach a katsayısı ve madde-toplam puan korelasyonu ile yapildı. Cronbach a güvenilirlik katsayısı değerinin büyüklüğüne göre ölçeğin güvenilirliği ve iç tutarlığı; $\alpha<0.40=$ güvenilir değil, $0.40 \leq \alpha<0,50=$ çok düşük güvenilirlik düzeyi, $0.50 \leq \alpha<0,60=-$ düşük güvenilirlik düzeyi, $0.60 \leq a<0,70=$ yeterli güvenilirlik düzeyi, $0.70 \leq \alpha<0,90=$ yüksek güvenilirlik düzeyi, $\alpha \geq 0,90=$ çok yüksek güvenilirlik düzeyine sahip olarak değerlendirilmelidir (25). Yapı Geçerliliği için açıklayıcı faktör çözümlemesi kullanıldı. Temel bileşenler analizi yapıldı. Verilerin uygunluğu değerlendirmek amacıyla Bartlett testi ve Kaiser- Meyer-Olkin (KMO) hesaplandı. KMO ölçütü 0.90-1.00olduğunda mükemmel, 0,80-0,89 arasında çok iyi, 0.70-0.79 arasında olduğunda iyi, 0.60-0.69 arasında olduğunda orta, 0,50-0,59 arasında olduğunda zayıf ve 0,50'nin altında kabul edilemezdir $(20,26)$.

\section{Etik Boyut}

Araştırma için bir Üniversite'nin Girişimsel Olmayan Klinik Araştırmalar Etik Kurulu'ndan yazılı izin alındı (22/04/2018 tarih ve 2018/4-34 sayll1). Araştırma için Leiden Ameliyathane ve Yoğun Bakım Güvenliği Ölçeği’nin kullanımı için ölçeği oluşturan ekipte yer alan Dr. M. Van Beuzekom'dan izin alındı (24.11.2016). Araştırmanın yapıldığı iki üniversite hastanesinden yazılı izin alındı(53911808-929 ve 84776830-180.99). Araştırmanın amacı hakkında bilgi verildikten sonra sağlık çalışanlarından yazılı ve sözel izin alındı 


\section{BULGULAR}

Çalışmaya katılan sağlık çalışanlarının sosyodemografik ve mesleki özellikleri Tablo 1'de verildi.

Çalışmaya katılan sağlık çalışanlarının yaş ortalaması $28,71 \pm 6,31$ yıl olup \%55,8’i (n=178) kadındır. Sağlık çalışanlarının \%60,8'i ( $n=194)$ lisans, \%14,1'i ( $n=45)$ önlisans, \%12,9’u ( $n=41)$ lise, \%12,2'si (n=39) lisansüstü mezunudur. Sağlık çalışanlarının tamamı üniversite hastanesinde çalışmakta olup \% 56,1'i ( $n=179$ ) yoğun bakımda, \% 37,0'1 $(n=118)$ ameliyathanede ve \% 6,9'u $(n=22)$ hem yoğun bakım hem de ameliyathanede çalıșmaktadır. Sağlık çalıșanlarının meslekte çalışma yılı ortalama $6,50 \pm 5,88$, çalıştıkları birimde çalışma yılı ortalamaları ise 4,32 $\pm 4,44$ yıldır (Tablo 1). Sağlık çalışanlarının \% 39,8’i (n=127) hemşire, \% 32,6’sı (n=104) anestezi uzmanı, \% 18,8'i (n=60) hekim, \% 4,7'si
( $\mathrm{n}=15)$ anestezi teknisyeni ve \% 4,1'i $(\mathrm{n}=13)$ ameliyathane teknikeridir (Şekil 1).

Dil geçerliği sağlanan Leiden Ameliyathane ve Yoğun Bakım Güvenliği Ölçeği'nin kapsam geçerlik indeksi 0,99 bulundu. Ölçeğin toplam Cronbach a katsayısı 0,89 olup yüksek güvenirlik derecesine sahip olduğu belirlendi. Madde toplam puan korelasyonunda 12., 13., 16., 17., 19., 46., 52., 54., 55. ve 59. maddeler hariç diğer tüm maddelerin korelasyon katsayıları 0,258 ile 0,666 arasında ve $\mathrm{p}<0,001$ olarak bulundu. Madde toplam puan korelasyon değerleri 12., 13., 16., 17., 46. ve 52. maddelerde istatistiksel olarak anlaml1, 19., 54., 55. ve 59. maddelerde istatistiksel olarak anlamsız olmakla birlikte $\mathrm{r}=0.005$ ile 0.203 arasında olup istenilen düzeyden düşük olduğu saptandı. Bu maddelerin ölçekten çıkarılmasına karar verildi.

\section{Tablo 1. Sağlık Çalışanlarının Sosyodemografîk ve Mesleki Özelliklerine Göre Dağılımı}

\begin{tabular}{|c|c|c|c|c|}
\hline Özellikler & $\mathbf{N}$ & $\bar{X}$ & SS & Min.-Max. \\
\hline Yaş & 319 & 28,71 & 6,31 & $20-56$ \\
\hline Meslekte Çalışma Yılı & 319 & 6,50 & 5,88 & $1-32$ \\
\hline \multirow[t]{2}{*}{ Birimdeki Çalışma Yılı } & 319 & 4,32 & 4,44 & $1-26$ \\
\hline & & & Sayı (n) & Yüzde (\%) \\
\hline \multirow[t]{2}{*}{ Cinsiyet } & \multicolumn{2}{|l|}{ Kadın } & 178 & 55,8 \\
\hline & \multicolumn{2}{|l|}{ Erkek } & 141 & 44,2 \\
\hline \multirow[t]{4}{*}{ Öğrenim Durumu } & \multicolumn{2}{|l|}{ Lise } & 39 & 12,2 \\
\hline & \multicolumn{2}{|l|}{ Ön Lisans } & 45 & 14,1 \\
\hline & \multicolumn{2}{|l|}{ Lisans } & 194 & 60,8 \\
\hline & \multicolumn{2}{|l|}{ Lisansüstü } & 41 & 12,9 \\
\hline \multirow[t]{3}{*}{ Çalıştı̆̆ Birim } & \multicolumn{2}{|c|}{ Ameliyathane } & 118 & 37,0 \\
\hline & \multicolumn{2}{|c|}{ Yoğun Bakım Ünitesi } & 179 & 56,1 \\
\hline & \multicolumn{2}{|c|}{ Ameliyathane+Yoğun Bakım Ünitesi } & 22 & 6,9 \\
\hline
\end{tabular}

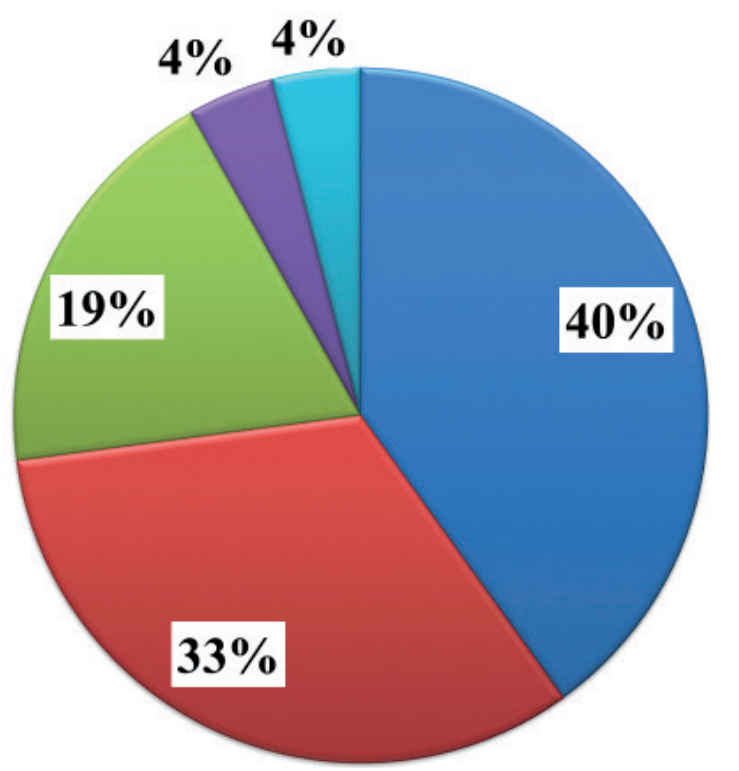

\section{回 Hemşire}

\section{Anestezi Uzmanı}

回 Hekim

Anestezi

Teknisyeni

Ameliyathane

Teknikeri

Şekil 1. Sağlık Çalışanlarının Mesleklerine Göre Dağılımı 
Tablo 2. Leiden Ameliyathane ve Yoğun Bakım Güvenliği Ölçeği'nin Madde Toplam Puan Korelasyon Değerleri, Faktör Yükleri, İç Tutarlılık Değerleri

\begin{tabular}{|c|c|c|c|c|c|}
\hline 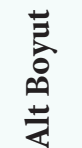 & İfadeler & $\begin{array}{l}\text { Madde Toplam } \\
\text { Puan Korelasyon } \\
\text { Değerleri }\end{array}$ & $\begin{array}{l}\text { Faktör } \\
\text { Yükleri }\end{array}$ & $\begin{array}{l}\text { Cronbach } \\
\text { Alfa } \\
\text { Değerleri }\end{array}$ & $\begin{array}{l}\text { Alt boyut } \\
\text { Cronbach } \\
\text { Alfa Değeri }\end{array}$ \\
\hline \multirow{11}{*}{ 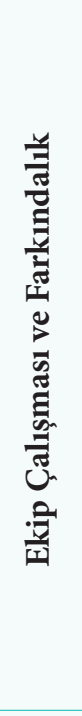 } & 36.Ekip üyeleri birbirlerini sorunlara karşı uyarır. & .59 & .730 & .72 & .90 \\
\hline & $\begin{array}{l}\text { 34.Ekip üyeleri, uyumlu bir ekip olarak birlikte } \\
\text { iyi çalışır. }\end{array}$ & .66 & .728 & .72 & \\
\hline & 37.Ekip üyeleri, birbirinin ne yaptığını bilir. & .57 & .727 & .72 & \\
\hline & 35.Kimin neyi ne zaman yapacağı nettir. & .63 & .640 & .72 & \\
\hline & 38.Ekip üyeleri, birbirlerinin performansını izler. & .54 & .599 & .72 & \\
\hline & 43.Birbirimizin fikrini dinleriz. & .61 & .579 & .72 & \\
\hline & $\begin{array}{l}\text { 33.Ekibin beklenmedik olaylar ile başa çıkabilme } \\
\text { yeteneği vardır. }\end{array}$ & .55 & .549 & .72 & \\
\hline & $\begin{array}{l}\text { 32.Gerçekten çalıştığım ekibin bir parçası } \\
\text { olduğumu hissediyorum. }\end{array}$ & .60 & .503 & .72 & \\
\hline & 45.İş ile ilgili eleştirilere açıktır. & .58 & .475 & .72 & \\
\hline & $\begin{array}{l}\text { 39.Ameliyat/vardiya sırasında yeterli bilgi } \\
\text { aktarımı vardır. }\end{array}$ & .62 & .474 & .72 & \\
\hline & 41.Çalışma ortamı her zaman temizdir. & .50 & .365 & .72 & \\
\hline \multirow{10}{*}{ 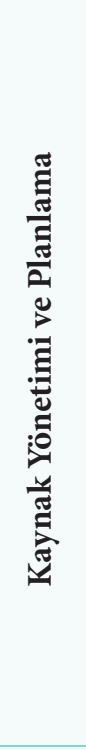 } & $\begin{array}{l}\text { 23.Bakım onarım hizmetleri programı geç } \\
\text { yapılır.* }\end{array}$ & .39 & .636 & .72 & .81 \\
\hline & $\begin{array}{l}\text { 57.Prosedürler/yönetmelikler/kurallar genellikle } \\
\text { pratikte uygulanabilir değildir.* }\end{array}$ & .25 & .580 & .72 & \\
\hline & 15.Sadece kısa vadeli planlar yapılır.* & .38 & .569 & .72 & \\
\hline & $\begin{array}{l}\text { 56.Prosedürler/yönetmelikler/kurallar açık } \\
\text { değildir.* }\end{array}$ & .29 & .561 & .72 & \\
\hline & $\begin{array}{l}\text { 14.Bölüm içerisinde önceden planlama eksikliği } \\
\text { vardır.* }\end{array}$ & .42 & .560 & .72 & \\
\hline & 22.Ekipman kötü bir şekilde korunur.* & .35 & .555 & .72 & \\
\hline & 24.Malzeme ve ekipman düşük kalitelidir.* & .36 & .503 & .72 & \\
\hline & 40.Malzemeler genellikle gelişigüzel depolanır.* & .33 & .491 & .72 & \\
\hline & $\begin{array}{l}\text { 18.Ekranların kontrolü anlaşılmaz ve/ya da } \\
\text { eksiktir.* }\end{array}$ & .33 & .489 & .72 & \\
\hline & $\begin{array}{l}\text { 42.Uygun ekipman düzenlemesi genelde } \\
\text { mümkün değildir.* }\end{array}$ & .30 & .488 & .72 & \\
\hline \multirow{6}{*}{ 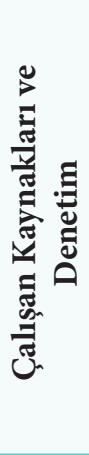 } & $\begin{array}{l}\text { 50.İyi bakım sağlamak için yeterli destek } \\
\text { personeli vardır. }\end{array}$ & .473 & .850 & .72 & .79 \\
\hline & 49.İyi bakımı sağlamak için yeterli çalışan vardır. & .473 & .807 & .72 & \\
\hline & 51.İyi bakım sağlamak için yeterli doktor vardır. & .405 & .530 & .72 & \\
\hline & 53.Yeterince deneyimli ulaşılabilir doktor vardır & .462 & .451 & .72 & \\
\hline & $\begin{array}{l}\text { 21.Bakım onarım hizmetleri zamanında } \\
\text { denetlenir. }\end{array}$ & .507 & .404 & .72 & \\
\hline & $\begin{array}{l}\text { 58.Prosedürler/yönetmelikler/kurallar doğru bir } \\
\text { şekilde uygulanır. }\end{array}$ & .418 & .322 & .72 & \\
\hline
\end{tabular}




\begin{tabular}{|c|c|c|c|c|c|}
\hline 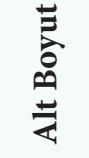 & İfadeler & $\begin{array}{l}\text { Madde Toplam } \\
\text { Puan Korelasyon } \\
\text { Değerleri }\end{array}$ & $\begin{array}{l}\text { Faktör } \\
\text { Yükleri }\end{array}$ & $\begin{array}{l}\text { Cronbach } \\
\text { Alfa } \\
\text { Değerleri }\end{array}$ & $\begin{array}{l}\text { Alt boyut } \\
\text { Cronbach } \\
\text { Alfa Değeri }\end{array}$ \\
\hline \multirow{5}{*}{ 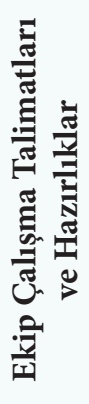 } & $\begin{array}{l}\text { 29. Ekip üyeleri, ameliyat/vardiya sırasında onları } \\
\text { nelerin beklediğine dair bilgilendirme yapılır. }\end{array}$ & .567 & .759 & .72 & .44 \\
\hline & $\begin{array}{l}\text { 30.Ekip üyeleri, ameliyat/vardiya sırasında yeterince } \\
\text { açılama yapılır. }\end{array}$ & .536 & .685 & .72 & \\
\hline & $\begin{array}{l}\text { 27.Yıpranmış veya hatalı ekipman zamanında } \\
\text { değiştirilir. }\end{array}$ & .531 & .479 & .72 & \\
\hline & $\begin{array}{l}\text { 26.İhtiyaç durumunda malzeme ve ekipman hazır } \\
\text { bulunur. }\end{array}$ & .487 & .430 & .72 & \\
\hline & 28.Ekipman sık sık tamir edilir.* & .282 & .345 & .72 & \\
\hline \multirow{8}{*}{ 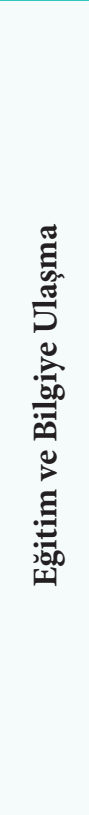 } & $\begin{array}{l}\text { 2.Çalışanlar yeni tıbbi/teknolojik gelişmeler } \\
\text { hakkında yeterli bilgiye sahiptir. }\end{array}$ & .550 & .718 & .72 & .78 \\
\hline & $\begin{array}{l}\text { 3.Çalışanlar yeni bir cihazın kullanımı konusunda } \\
\text { iyi eğitilmiştir. }\end{array}$ & .562 & .697 & .72 & \\
\hline & $\begin{array}{l}\text { 4.Stajyerlerin uygulama sürecinde yeterli denetimi } \\
\text { vardır. }\end{array}$ & .519 & .469 & .72 & \\
\hline & $\begin{array}{l}\text { 6.Kıdemli/kıdemsiz dağılımından kaçınılır/Kıdemli } \\
\text { ve kıdemsiz arasında yeterli dağılım uygulanır. }\end{array}$ & .342 & .441 & .72 & \\
\hline & $\begin{array}{l}\text { 7.Ameliyathane/yoğun bakım programında/ } \\
\text { planlanmış işlemlerdeki değişiklikler hakkında } \\
\text { zamanında bilgi verilir. }\end{array}$ & .451 & .433 & .72 & \\
\hline & $\begin{array}{l}\text { 8.Ameliyathane/yoğun bakım programında/ } \\
\text { planlanmış işlemlerdeki değişiklikler doğru kanallar } \\
\text { kullanılarak bildirilir. }\end{array}$ & .376 & .420 & .72 & \\
\hline & $\begin{array}{l}\text { 9.Diğer disiplinlerle hastalar hakkındaki iletişim } \\
\text { yeterlidir. }\end{array}$ & .449 & .405 & .72 & \\
\hline & $\begin{array}{l}\text { 10.Gerekli olduğunda mevcut prosedürü } \\
\text { uygulamaya dair bilgi verilir. }\end{array}$ & .456 & .360 & .72 & \\
\hline
\end{tabular}

Leiden Ameliyathane ve Yoğun Bakım Güvenliği Ölçeği'nin son halinin madde toplam puan korelasyon değerleri, faktör yükleri, iç tutarlılık değerleri Tablo 2'de verildi.

49 madde ile yapılan açıklayıcı faktör analizinde 1., 5., 11., 20., 25., 31., 44., 47., 48., maddenin saptanan yüksek iki yük değeri arasındaki farkın 0.10 'dan düşük olması nedeniyle çıkarıldı. 40 madde ile yapılan açıklayıcı faktör analizinde özdeğeri biri aşan beş faktör elde edildi ve bu beş faktörün açıkladığı toplam varyans $\% 47,05$ olarak bulundu. Faktörler; Ekip Çalışması ve Farkındalık, Kaynak Yönetimi ve Planlama, Çalışan Kaynakları ve Denetim, Ekip Çalışma Talimatları ve Hazırlıklar ve Eğitim ve Bilgiye Ulaşma olarak belirlendi.

\section{TARTIŞMA}

Literatürde herhangi bir alanda, o alanla ilgili davranışları, tutumları vb. ölçmek için geliştirilen ölçme araçlarının geçerlik ve güvenilirliğinin saptanması ve geçerlik ve güvenirliğinin yeterli olduğundan emin olunması gerektiği vurgulanmaktadır (27). Bu nedenle bu çalışma ameliyathane ve yoğun bakımlarda çalışan sağlık çalışanlarının hasta güvenliğinde istenmeyen olaylara yol açan sisteme dayalı gizli risk faktörleri değerlendirmesinde kullanılan Leiden Ameliyathane ve Yoğun Bakım Güvenliği Ölçeği’nin Türkçe geçerlik ve güvenirliğini test etmek amacı ile metodolojik olarak yapıldı. Geçerlik ve güvenirlik yapılırken iç tutarlılık, dil, kapsam ve yapı geçerliği incelendi. 
Leiden Ameliyathane ve Yoğun Bakım Güvenliği Ölçeği'nin Türkçe'ye uyarlaması hemşire, anestezi uzmanı, hekim, anestezi teknisyeni ve ameliyathane teknikerleri ile yapıldı. Bu çalışmada sağlık çalışanlarının \%39,8'ini (n=127) hemşire, \%32,6'sinı ( $n=104)$ anestezi uzmanı ve \%18,8'ini $(n=60)$ hekimler oluşturmaktadır. Leiden Ameliyathane ve Yoğun Bakım Güvenliği Ölçeği araştırmada ameliyathane ve yoğun bakımda çalışan hemşire ve hekimlerin bildirimleri doğrultusunda geliştirilmiştir. Van Beuzekom ve ark., tarafından (2007) ölçeğin geliştirildiği araştırmaya katılan sağlık çalışanlarının \%40'ı ameliyathanede ve \%47'si yoğun bakımlarda çalışmaktadır (19). Bu çalışmada ise sağlık çalışanlarının $\% 56,1$ 'i sadece yoğun bakım ve \%37.0'i sadece ameliyathanede çalışmaktadır.

Leiden Ameliyathane ve Yoğun Bakım Güvenliği Ölçeğinnin içerik geçerliğini incelemek amacıyla KGİ hesaplandı. İçerik-kapsam geçerliliğini saptama özellikle ölçek geliştirme çalışmalarında yapılması gereken önemli bir aşamadır (2831). Geçerlik sınamasının amacı, ölçme aracında bulunan maddelerin ölçülmek istenen alanı/davranışı temsil edip etmediğinin bir uzman grubu tarafından incelenerek anlamlı maddelerden oluşan bütünü oluşturmaktır. Uzmanların önerileri ve eleştirileri doğrultusunda ölçek yeniden yapılandırılmaktadır. Ölçekteki 59 maddenin kapsam geçerliliği için sekiz uzmanın verdiği puanlara göre yapılan Leiden Ameliyathane ve Yoğun Bakım Güvenliği Ölçeğinin KGİ 0,99 olarak bulundu. Uzmanların maddelerin içeriği konusunda görüş birliğine vardıkları saptand1.

Ölçeğin iç tutarlılığını değerlendirmek için yapılan bir diğer test ise madde istatistikleri olup korelasyon katsayılarının yüksek olması gerektiği belirtilmektedir (30,32). Yapılan madde analizi sonucunda madde toplam puan korelasyon değerlerinin .02 ile .66 arasında olduğu belirlenmiştir. Madde seçiminde kabul edilebilir korelasyon katsayısının 0,25'ten büyük olması önerilmektedir $(32,33)$. Ölçekte her madde için elde edilen korelasyon katsayısının yüksek olması, o maddenin amaçlanan davranışı ölçmede etkin ve yeterli olduğunu gösterir. Madde toplam puan korelasyon katsayısının hangi ölçütün altında güvenirliğinin yetersiz sayılacağ literatürde belirli bir standart değer belirtilmemektedir (34). Son kaynaklara göre korelasyon değeri .25 'in altında olması halinde ölçekten çıkarılması önerilmekle birlikte, bunun kesin bir kural olmadığı, madde çıkarıldığında alfa katsayısındaki değişime bakılarak karar verilmesi gerektiği vurgulanmaktadır $(32,35)$. Madde toplam puan korelasyon değeri .25 'in altında olan maddeler (10 madde) ölçek taslağından çıkarılarak geri kalan 49 madde üzerinden diğer istatistiksel analizler yapılmıştır. Leiden Ameliyathane ve Yoğun Bakım Güvenliği Ölçeği’nin iç tutarlılık analizinde 10 maddenin toplam madde korelasyonu 0.25 'in altında saptanmıştır.

Ölçeğin geliştirilme aşamasında alt boyutlar arasında Cronbach a güvenilirlik katsayısı 0,75 ile 0,88 arasında değişmektedir (19). Bu çalışmada veri toplama aracının toplam Cronbach alfa katsayısı. 89, "Ekip Çalışması ve Farkındalık" alt boyutunda .90, "Kaynak Yönetimi ve Planlama” alt boyutunda .81, "Çalışan Kaynakları ve Denetim" alt boyutunda .79 “Ekip Çalışma Talimatları ve Hazırlıklar” alt boyutunda .44 ve "Eğitim ve Bilgiye Ulaşma" alt boyutunda .78 olarak bulunmuştur. Cronbach alfa katsayısının $0.60 \leq a<0.80$ arasında oldukça güvenilir, $0.80 \leq a<1.00$ arasında ise yüksek derecede güvenilir olduğu ifade edilmektedir. Ölçeğin Cronbach alfa katsayısı ne kadar yüksek olursa, bu ölçekteki maddelerin o ölçüde birbirleri ile tutarlı olduğu, likert tipi ölçeklerde alfa katsayısının yüksek olmasının ölçme aracının güvenirlik düzeyinin yüksek olduğunu ve güvenilir bir şekilde kullanılabileceğini gösterdiği belirtilmektedir $(28,32,33,35)$. Leiden Ameliyathane ve Yoğun Bakım Güvenliği Ölçeği’nin, Cronbach a güvenilirlik katsayısının 0,89 olarak bulunması ölçeğin güvenilirliği ve iç tutarlığının yüksek güvenilirlik düzeyine sahip olduğunu göstermektedir.

Bir ölçeğin yapı geçerliliğini değerlendirmek üzere en fazla kullanılan iki yaklaşımdan birinin faktör analizi olduğu belirtilmektedir $(29,30)$. Faktör analizinde amaç çok say1daki maddenin daha az sayıda faktörlerle ifade edilmesidir. Aynı faktörü ölçen maddeler bir araya gelerek çeşitli gruplar oluşturmakta ve her faktör grubuna içinde bulunan maddelerin özelliğine göre bir faktör adı verilmektedir (29,31). Leiden Ameliyathane ve Yoğun Bakım Güvenliği Ölçeğinnin yapı geçerliliğini sınamak için yapılan 49 maddelik yapılan faktör analizi sonucunda 9 madde için saptanan yüksek iki yük değeri arasındaki fark 0,10'dan fazla olduğu için ölçekten çıkarılarak test tekrarlanmıştır. Analizler 40 madde ile tekrarlanmıştır. 40 maddenin beş faktör altında toplam varyansın \% 47,05 oranında açıkladığı görülmüştür. Yapılan faktör analizi sonucunda maddelerin faktör yüklerinin .25 - .66 arasında olduğu görülmüştür. Ölçeğin geliştirilme aşamasında yapılan faktör analizinde açıklanan toplam varyansın $\% 48,0$ oranında olduğu ve maddelerin faktör yüklerinin en az 0.40 olarak belirlendiği görülmüştür (19). Kültürel farklılıklara bağlı olarak ölçeğe yeni maddelerin eklenmesi, bazı maddelerin çıkarılması ya da değiştirilmesi söz konusudur. Dolayısıyla ölçekteki bir maddenin uyarlama yapılan kültüre uygun olmaması durumunda madde ya değiştirilir ya da tamamen anketten çıkarılır. Yapılan çalışmalardaki farklılıklar ölçeğin algılanmasındaki kültürel farklılıklardır. Literatürde, uyarlanan bir ölçeğin faktör yapısı orijinal ölçeğin faktör yapısı ile karşılaştırılarak, pratikte bu faktörlerin büyük oranda benzeşik olması yeterli görülmekte ve orijinal ölçekteki faktör yapıları benimsenmektedir $(30,33)$. Bu çalışmada da elde edilen faktör dağılımı, orijinal ölçeğin dağılımı ile uyumlu bulunmuştur. Faktörler; Ekip Çalışması ve Farkındalık, Kaynak Yönetimi ve Planlama, Çalışan Kaynakları ve Denetim, Ekip Çalışma Talimatları ve Hazırlıklar ve Eğitim ve Bilgiye Ulaşma olarak belirlenmiştir.

Leiden Ameliyathane ve Yoğun Bakım Güvenliği Ölçeği'nin, Türkçe geçerlik güvenirlik analizleri sonucunda 40 madde ve 5 alt boyuttan (Ekip Çalışması ve Farkındalık=11 madde, Kaynak Yönetimi ve Planlama=10 madde, Çalışan 
Kaynakları ve Denetim=6 madde, Ekip Çalışma Talimatları ve Hazırlıklar=5 madde ve Eğitim ve Bilgiye Ulaşma=8 madde) oluştuğu, madde toplam puan korelasyonu değerlerinin .25 ile .66 arasında olduğu, toplam Cronbach alfa değerinin .89 alt boyut Cronbach alfa değerlerinin ise .90, .81, .79, .44 ve .78 olduğu belirlenmiştir. Geçerlilik; dil geçerliği, kapsam geçerliliği ve yapı geçerliği ile sağlanmıştır.

$\mathrm{Bu}$ sonuçlar doğrultusunda ameliyathane ve yoğun bakımlarda çalışan sağlık çalışanlarının hasta güvenliğinde istenmeyen olaylara yol açan sisteme dayalı gizli risk faktörleri değerlendirmesinde kullanılan "Leiden Ameliyathane ve Yoğun Bakım Güvenliği Ölçeği’nin Türk toplumu için geçerli ve güvenilir bir araç olduğu saptanmıştır. Ölçek toplam 40 maddeden oluşmaktadır. Leiden Ameliyathane ve Yoğun Bakım Güvenliği Ölçeği'nin prospektif tanımlayıcı çalışmalarda kullanılması, diğer merkezlerde çalışan sağlık çalışanlarında sınanması ve daha büyük örneklem grubu ile çalışılması önerilmektedir.

\section{Çıkar Çatışması ve Finans Durumu}

Çalışmamız bir kurum ve kuruluşça finanse edilmemiştir. Bu çalışmada yazarlar arasında herhangi bir konuda çıkar çatışması bulunmamaktadır.

\section{Araştırmacıların Katkı Oranı Beyan Özeti}

Tüm yazarlar makaleye eşit olarak katkı sunmuştur.

\section{KAYNAKLAR}

1. Çırpı F, Merih YD, Kocabey MY. Hasta güvenliğine yönelik hemşirelik uygulamalarının ve hemşirelerin bu konudaki görüşlerinin belirlenmesi. Maltepe Üniversitesi Hemşirelik Bilim ve Sanatı Dergisi. 2009;2(3):26-34.

2. Akansel N. Ameliyathane Hemşireliği. van Giersbergen MY, Kaymakçı Ş. Uluslararası ve ulusal hasta güvenliği hedefleri ve uygulamalar, 1. Baskı İzmir, Metabasım, 2015;85-109.

3. van Giersbergen MY. Ameliyathane Hemşireliği. van Giersbergen MY, Kaymakçı Ş. Uluslararası ve ulusal hasta güvenliği hedefleri ve uygulamalar, 1. Baskı İzmir, Metabasım, 2015;131142 .

4. World Health Organization. Patient safety 2017. http://www. euro.who.int/en/health-topics/Health-systems/patient-safety (25.01.2020).

5. Altınbaş Y, Karaca T. Cerrahi hemşirelerinin hasta güvenliğine ilişkin deneyimleri: Nitel bir çalışma. İnönü Üniversitesi Sağlık Hizmetleri Meslek Yüksekokulu Dergisi. 2020;8(3):1-14.

6. Çakmakçı M, Akalın HE. Hasta güvenliği Türkiye ve Dünya, Ankara, Türk Tabipler Birliği, 2011.

7. Amalberti R, Auroy Y, Berwick D, Barach P. Five system barriers to achieving ultrasafe health care. Ann Intern Med, 2005;142(9):756-764.

8. Gürer A. Sağlık Hizmetlerinde Çalışan Güvenliği. Journal of Health Services and Education. 2018;2(1):9-14.

9. Tombe D. Hasta güvenliğini sağlamanın karmaşıklığı, karmaşıklığın insan ve sistem boyutları. 1. Hasta Güvenliği Kongresi Özet Kitab1, 28-31 Mart 2007, Antalya, s.24-28.

10. Sezgin B. Kalite belgesi alan hastanelerde çalışma ortamı ve hemşirelik uygulamalarının hasta ve hemşire güvenliği açısından değerlendirilmesi (Yükseklisans Tezi). İstanbul, İstanbul Üniversitesi, 2007.
11. Wolf ZR, Goldrick T, Flynn ER, Warwick F. Factors associated with a perceived harmful out-come from medication errors a pilot study. The Journal Of Continuing Education In Nursing, 1999;27(2):65-73.

12. Candaş B, Gürsoy A. Cerrahide hasta güvenliği: Güvenli cerrahi kontrol listesi. ERÜ Sağlık Bilimleri Fakültesi Dergisi, 2015;3(1):40-50

13. Erdağ $1 \mathrm{~S}$, Özer N. Cerrahi kliniklerde çalışan hemşirelerin çalışma ortamlarının, hasta güvenliği kültürü algılarının ve tükenmişlik durumlarının incelenmesi. Journal of Anatolia Nursing and Health Sciences, 2015;18(2):94-106.

14. Rizalar S, Topçu SY. The patient safety culture perception of Turkish nurses who work in operating room and intensive care unit. Pak J Med Sci, 2017;33(2):374-379.

15. Wang M, Tao H. How Does patient safety culture in the surgical departments compare to the rest of the county hospitals in Xiaogan city of China?. Int J Environ Res Public Health. 2017;14(10):1123.

16. World Health Organization. Patient safety. Global action on patient safety. https://apps.who.int/gb/ebwha/pdf_files/WHA72/ A72_26-en.pdf. (26 Mayıs 2020)

17. Soyer Ö, Giersbergen MY. Güvenli cerrahi kontrol listesinin etkinliği: Sistematik inceleme. Journal Of Anatolia Nursing And Health Sciences, 2017;20(4):286-298.

18. Hisar A. Sağlik hizmetlerinde risk yönetiminin çalışan güvenliğine etkisi ve bir uygulama (Yükseklisans Tezi). İzmir, Dokuz Eylül Üniversitesi, 2013.

19. Van Beuzekom M, Akerboom SP, Boer F. Assessing system failures in operating rooms and intensive care units. BMJ Quality \& Safety. 2007;16(1):45-50.

20. Akgül A. Tibbi araştırmalarda istatistiksel analiz teknikleri spss uygulamaları. 3. Baskı. Ankara: Dilek Türk, 2005; s.28-29.

21. Çapık C, Gözüm S, Aksayan S. Kültürlerarası ölçek uyarlama aşamaları, dil ve kültür uyarlaması: Güncellenmiş rehber. FNJN Florence Nightingale Journal of Nursing. 2018;26(3):199-210.

22. Van Beuzekom M, Boer F, Akerboom S, Patrick H. Patient safety in the operating room: an intervention study on latent risk factors. BMC Surgery. 2012;12:10.

23. Davis LL. Instrument review: Getting the most from a panel of experts. Appl Nurs Res. 1992;5:194-97.

24. Yurdugül H. Ölçek geliştirme çalışmalarında kapsam geçerliği için kapsam geçerlilik indekslerinin kullanılması. XIV. Ulusal Eğitim Bilimleri Kongresi Özet Kitabı, Denizli, 200530 Eylül;28.

25. Özdamar K. Paket programlar ile istatistiksel veri analizi, Ankara, Nisan Kitabevi, 2013.

26. Kartal M, Bardakçı S. SPSS ve AMOS uygulamalı örneklerle güvenirlik ve geçerlik analizleri, Ankara, Akademisyen Kitabevi, 2018.

27. Erkuş A. Psikometri üzerine yazılar. 1. Basım, Ankara, Türk Psikologlar Derneği Yayınları, 2003;72-150.

28. Büyüköztürk Ş. Sosyal bilimler için veri analizi el kitabı. 6. Bask1, Ankara, Pegem A Yayıncılık, 2006.

29. Erefe İ. Hemşirelikte araştırma ilke süreç ve yöntemleri. İstanbul, 2002.

30. Gözüm S, Aksayan S. Kültürlerarası ölçek uyarlaması için rehber II: Psikometrik özellikler ve kültürler arası karşılaştırma. Hemşirelikte Araştırma Geliştirme Dergisi. 2002;4(2):9-20.

31. Karasar N. Bilimsel araştırma yöntemi. 10. Baskı, Ankara, Nobel Kitapevi, 2000.

32. Özdamar K. Paket programlar ile istatistiksel veri analizi I. Genişletilmiş 5. Baskı, Eskişehir, Kaan Kitabevi, 2004. 
33. Baykal Ü, Şahin NH, Altuntaş Ş. Hasta güvenliği tutum ölçeği’nin Türkçe’ye uyarlanması. Hemşirelikte Eğitim ve Araştırma Dergisi. 2010;7(1):39-45.

34. Türkmen E, Baykal Ü, Seren Ş, Altuntaş S. Hasta Güvenliği kültürü ölçeği'nin geliştirilmesi. Anadolu Hemşirelik ve Sağllk Bilimleri Dergisi. 2011;14(4):38-46.

35. Kalaycı Ş. SPSS uygulamalı çok değişkenli istatistik teknikleri, 1. Baskı, Ankara, Asil Yayın Dağıtım, 2005. 